\title{
CLASS AND THE DIRTY WORK OF WAR IN CALDERÓN
}

\author{
Margaret R. Greer \\ Duke University
}

[Anuario calderoniano (ISSN: 1888-8046), 2, 2009, pp. 207-218]

A long-standing debate among calderonistas revolves around the punishment of the rebel soldier in La vida es sueño who sparked the rebellion that overthrew the king, Basilio and brought to power Segismundo, the son whom the king had kept in a secret prison. Some argue that it is patently unjust and reveals Calderón's sense of the unjust foundations of monarchical rule, or the imperfection of human society. Others attribute it to a prudent reason of state that condemns treachery to the established order even to achieve a desired end, and blame the soldier's self-serving claim that he deserves a reward. Like most $21^{\text {st }}$ century readers and spectators, who often gasp aloud at the edict that the rebel soldier be sent to the tower prison, my political sympathies ally me with the soldier. But my objective herein is to question my own wish to attribute that position to Calderón, and to illuminate that debate from the perspective of several other Calderonian dramas of war and rebellion that include attention to soldiers. Bringing into my treatment consideration of the changing status of military service in early modern Spain as the army became 
semi-professional, I suggest that Calderón regularly assigns the dirty but necessary work of war to self-serving actions of lower-class characters whom he depicts unfavorably, thereby safeguarding an aristocratic ideology of the nobility of military service by upper-class officers. But what emerges is not a simple one-dimensional picture.

El Tuzaní de la Alpujarra, (or Amar después de la muerte) on the morisco revolt in the Alpujarras of 1568-1570, brutally put down by troops commanded by don Juan de Austria, is the work that centered my attention on Calderonian soldiers. As I have argued elsewhere, I believe that Calderón - revered for his service to the Catholic faith in his autos sacramentales and dramas of conversion- in this work conveys much sympathy for a rebellious morisco population, long after their expulsion from Spain between 1609 and 16041. Reading today his scenes of Christian forces mining, exploding and sacking the morisco city Galera, of a greedy soldier Garcés brutally slaying the beautiful young bride Maleca to steal the wedding jewels the Tuzaní had just given her in a marriage left unconsummated by the outbreak of the Alpujarras war, calls up recent scenes of the destruction in Bagdad and the siege of Faluja in the US-led war that also victimizes innocent Iraqui women and children. It was certainly don Juan who ordered the mining of Galera. Luis de Mármol Carvajal reported his vow to destroy it: "Yo hundiré a Galera y la asolaré y sembraré toda de sal, y por el riguroso filo de la espada pasarán chicos y grandes cuantos están dentro, por castigo de su pertinacia y en venganza de la sangre que han derramado» ${ }^{2}$. As Erik Coenen points out, both Mármol Carvajal and Ginés Pérez de Hita attribute to don Juan the command to kill all the town's occupants ${ }^{3}$. In Calderón's play, don Juan calls the rebellious mountain stronghold an «infame ladronera» that he will punish with vengeance, although he says it will bring him little applause, because «esto matar y no vencer se llama» ${ }^{4}$. Yet Calderón makes the idea originate not with don Juan but with the Christian foot soldier Garcés, who discovers an ideal point to mine the walls of the moun-

1 Greer, 2006.

${ }^{2}$ Mármol Carvajal, Historia de la rebelión, p. 219, quoted in Coenen, 2008, p. 34.

3 Coenen, 2008, pp. 34-35.

${ }^{4}$ Calderón de la Barca, El Tuzaní de la Alpujarra, line 895. 
tain stronghold while pursuing his escaped prisoner, don Álvaro's comic lacayo, Alcuzcuz.

It is not fortuitous that Calderón criss-crosses the fortunes of the morisco gracioso and Garcés. Although Garcés (neither first name or rank indicated) claims to be ambitious for honor, not for gain, Calderón makes him the incarnation of the most destructive passions of war, the desire for revenge, greed, and lust as well as racio-religious prejudice. This assignment is in fact relatively accurate in an era in which military service was no longer the distinctive province of aristocrats and their subjects, but depended on an army populated by mercenary soldiers and ill-paid (or unpaid) draftees. The army was left halfway between a professional, disciplined force and one which depended on anticipation of its share of the yield of stealing enemy wealth and enslaving captives, something which both Pérez de Hita and Diego Hurtado de Mendoza condemn in their histories of the rebellion as a factor that enlarged and prolonged it, provoking otherwise peaceful morisco communities to join in.

Remembering a similar Calderón location of the dirty work of war in El sitio de Bredá sent me back to reread this drama on the famous and famously expensive siege, Olivares may have commissioned the play shortly after the news of Breda's surrender reached Madrid in 1625 , as Shirley Whitaker maintains ${ }^{5}$, or it may have been written some three years later, to honor Spínola on his 1628 visit to the "coronada villa», as Simon Vosters argues ${ }^{6}$. Coenen does not give a date from the play, but presumably opts for the later date, since he considers Calderón's undoubted source to have been the Obsidio Bredana, Hermann Hugo's account of the events in the Low Countries, published in Antwerp in 1626 and in Spanish translation in 16277.

In El sitio de Bredá, the voice of war's 'dirty work' is one significantly-named Alonso Ladrón. Vosters suggests that Calderón drew the name - but not the character's nature- from the booklet La descripción de la villa $y$ sitio de Bredá made to accompany Callot's artistic map of Breda. Without condoning in any way Protestant apostasy, Calderón in this play, as in El Tuzaní, displays a human sympathy for the suffe-

\footnotetext{
5 Whitaker, 1978.

${ }^{6}$ Vosters, 1981

7 Coenen, 2006, p. 32.
} 
ring of the besieged populace, and respect for their leaders, including the Welshman Charles Morgan. As the excellent analysis of Gridley McKim-Smith and Marcia Welles points out, he makes this theatrical pageant «an ideal mirage of national, aristocratic values», a dramatized polemical response to the Black Legend of Spanish cruelty in combat and the uses made in the Protestant propaganda mill of the Duke of Alba's cruel and bloody tactics of repressive policies earlier in this protracted war'.

Spinola reviews the multi-national troops in the huge force assembled for the siege, Ladrón points out the Italians and Walloons, and Spínola says "Sufren mucho en un sitio estos soldados», to which Ladrón responds ironically, «Si el saco esperan, sí». Spinola defends them saying, «No los baldones, que pelean también» drawing from Ladrón the sardonic rejoinder, «Si están pagados», which he follows up with contrasting praise for the Spanish forces (who in fact constituted only $10 \%$ of the force $)^{9}$. Spínola recognizes the importance of the hope of a lucrative sack in preventing mutiny during a long cold siege:

Si no están entretenidos
los soldados en algunos
de los sitios que se ofrecen
$[\ldots]$ podrán
amotinarse; y no dudo
que la esperanza del saco
pueda sufrir con más gusto
el grave peso a las armas ${ }^{10}$

But when they surrender, he prevents any soldierly looting, thus in effect using the idea of a sack to control the imperial troops similarly to his feigned march to Graves that drew rebel forces away from the defense of Breda. Deterring that self-payment, Spinola then offers the Burgundian, Scottish and English troops the wealth of his own tent as a substitute. When the foreign mercenary troops grumble over that limited prospect, Spínola queries the Spanish troops, who offer

8 McKim-Smith and Welles, 1992, pp. 190-191.

${ }^{9}$ Calderón de la Barca, El sitio de Bredá, p. 73.

${ }^{10}$ Calderón de la Barca, El sitio de Bredá, p. 75. 
to give the king their own share so that the king's victory might not be stained by blood. Thus, Calderón, who concludes this play with the disclaimer that he could do no more, being subject to so many commands, dramatizes Spanish soldiery en masse as valiant and generous.

Calderón also invents scenes showing the noble courtesy the Spanish captain don Fadrique Bazán shows a Flemish widow and her son caught outside the walls, in contrast to the delight that Ladrón takes in the suffering of their enemies, saying of the peasants who fled their houses torched by Spanish troops:

¡Oh, qué maldita canalla!
Muchos murieron quemados,
y tanto gusto me daba
verlos arder, que decía,
atizándoles la flama:
«Perros herejos, ministro
soy de la Inquisición santa» ${ }^{11}$.

Although Spínola calls Ladrón «capitán», Calderón does not bestow on him the "don» of nobility or the chivalrous courtesy and generosity with which he endows noble officers, both Catholic and Protestant. Implicitly, this reflects the debate over whether captaincies and higher command posts should be conferred on the basis of military experience, as preferred by the drive toward professionalization of the military forces during the reign of Philip II, or awarded to possessors of noble blood, a distinguished family name, and the recruiting efficiency of landed nobility. The latter option became increasingly the rule with the rearistocratization of command of Spanish forces to which the monarchy resorted under that the economic strain of multiple foreign wars and declining revenues ${ }^{12}$.

In El alcalde de Zalamea (1640-44?), set in 1581 as Spanish troops travel toward Portugal to secure Philip II's claim as monarch, Calderón dramatized the disorder created by the passage of troops through the Spanish countryside and their billeting along the way. There is no need to retell the story of this famous drama, in which the rabble-rousing

11 Calderón de la Barca, El sitio de Bredá, p. 81.

12 Thompson, 1976, p. 121. 
and complaints of foot soldiers and camp followers are personified by Rebolledo and his woman, La Chispa. I. A. Thompson's study War and Government in Habsburg Spain 1560-1620 gives eloquent testimony to the reality of such disorder:

The annual movement of forty or more companies across Castile left in its wake a trail of destruction and rapine. An endless series of robberies, murders, rapes, malicious and wanton violence, jailbreaks, even pitched battles between soldiers and civilians repeated year after year stretched along all the most traversed routes of the kingdom. The coming of a company of soldiers was awaited with the same trepidation as a hurricane. Those who could fled its path; those who could not were forced to abandon their trades to stay at home to protect their wives, their daughters and their property ${ }^{13}$.

In this drama, however, Calderón shows that the presence of an aristocratic captain might not prevent, but rather provoke tragedy. Rather than disciplining his subordinates, the Capitán don Álvaro de Ataide stages a fight with Rebolledo as a pretext to have access to the daughter whom Crespo has prudently hidden from view, and he later kidnaps and rapes her. In the tragedy, the king arrives in time to sanction Crespo's execution of the captain, but in real life, as Thompson points out, the king could not step in to solve bureaucratic and jurisdictional honor conflicts that trapped royal officials attempting to impose order and discipline ${ }^{14}$.

Furthermore, despite the grounding of aristocratic privilege on the nobility's duty to perform military service, as the seventeenth century progressed, many nobles were increasingly reluctant to take up arms. In the 1640s, with multiple foreign wars compounded by rebellions in Cataluña and Portugal, Chile, the Philippines, and Goa, generalized hatred of the Olivares regime even led to what Marañon labeled «la huelga de los grandes», many of whom abandoned the court and ignored Olivares' attempt to impose taxes on them and to compel them to perform military service. His attempts to form a battalion of 2000 cavalrymen from the court of Madrid to serve in Portugal failed (only 150 members of the military orders appeared for the king's review in

13 Thompson, 1976, pp. 113-114.

14 Thompson, 1976, p. 46. 
the Buen Retiro in the autumn of $1640^{15}$ ). A number of nobles argued that they were not obliged to join a campaign unless they went accompanying the king. Although it had been announced for several years that Philip IV would assume leadership close to the battle zone, Olivares opposed it - which his enemies attributed less to his fears for the king's safety that his own fear of losing control over him ${ }^{16}$. Calderón, however, did respond to the call to arms, appearing mounted to join a cavalry company in May of 1640 , and he continued to serve in Cataluña until November, 1642, when he was released because of ill health. In the autumn of 1641, he was sent from Tarragona to Madrid to give Philip IV an account of the distressing conditions of the troops, and remained there several months ${ }^{17}$.

While in Madrid, Calderón wrote a fascinating and little studied auto sacramental entitled El divino cazador for performance in the 1643 Corpus Christi celebration. Given the gravity of the military situation, and the generalized hope of the moral effect of his leadership, the Junta de Ejecución approved the king's assumption of that role in August of 1641, but it had to be postponed for a year because the flotilla did not arrive from America and finances did not permit it. Although he did leave Madrid in April of 1642, skeptics doubted he would ever reach the front, that Olivares would keep him entertained hunting in the royal reserves and similar diversions ${ }^{18}$. Time and space limitations do not permit extended analysis here of the political implications of Calderón's auto in these circumstances, but as I have written elsewhere, I believe that Calderón made it his dramatic support of those calling for Philip IV to take personal command of the troops ${ }^{19}$. In the auto, in response to the pleas of Género Humano, the celestial Monarch agrees to send to their assistance his son, the Prince, disguised as a divine hunter, armed with an harquebus - the arm Philip carries in Velázquez's portrait of him as a hunter - with which to destroy the demonic enemy who has provoked general rebellion in

15 Domínguez Ortiz, 1955; Stradling, 1988, p. 120; Elliott, 1986, p. 610.

16 Domínguez Ortiz, 1955, pp. 802-815; Stradling, 1988, pp. 103-104, 118, 212217; Elliott, 1986, pp. 623, 626-631.

17 Wilson, 1971, pp. 801-802; Cotarelo y Mori, 1924, p. 235; Varey and Davis, 1992.

18 Domínguez Ortiz, 1955, p. 815, Elliott, 1986, pp. 623-628.

19 Greer, 1997. 
the terrestrial realm. Thus incarnated, he will descend to earth, he says, because «la vista del Príncipe saliendo / solo a mirar, acabará la guerra» ${ }^{20}$.

At the opposite end of the divine-demonic spectrum and on the other side of the Atlantic, Calderón envisions and dramatizes the same tacit class structure in La aurora en Copacabana (c.1661), on the conquest and Christianization of Peru and a supposedly miraculous intervention of the Virgin Mary in that process. Briefly, he creates a classic Spanish gracioso named Tucapel (taking the name from Ercilla and Lope), whom he makes the mouthpiece of Idolatry's efforts to retain the loyalty of the natives to her cult. Granted, he shares the honors with an Atabaliba (Atahualpa) whom Calderón pictures as subject to the same destructive amorous passions used to question imperfect Castilian kings in a multiplicity of dramas.

Lastly, let me draw attention to another little-studied and undervalued late drama, El segundo Scipión, that merits attention for its presentation of a class-based view of military ethics. Undervalued not because it is a dramatic masterpiece, but because it takes on new interest in the political situation in court at the time of its estreno, in November, 1677, as an elaborately staged court play in the Buen Retiro theater for the birthday celebration of the queen mother, Mariana. Carlos II, then 17, was still not mentally or physically fit to rule. The drive to power of his illegitimate half-brother don Juan José had finally achieved success with his march from Aragón toward Madrid with a gathering army of supporters, bringing him to enjoy effective governing power in Jan. 1677, displacing both Mariana's Austrian confessor Nithard and the upstart Fernando Valenzuela whom she favored $^{21}$. In this context, Calderón's puts on stage not two but we might say four classes of «soldiers»:

1) an idealized general conquering the Spanish Carthage as much with his magnanimity and exaggerated courtesy to the women whom the Carthaginian ruler Magón had expelled from the wall city in anticipation of a siege as with his military skill and might;

2) scrapping common soldiers, Brunel and Turpín, who are first

20 Calderón de la Barca, El divino cazador, lines 682-683.

${ }^{21}$ Kamen, 1980, pp. 337-340; Greer, 1991, pp. 148-150. 
displayed attempting to rob and violate those women; when Scipio sends both away saying they besmirch the name of soldiers, Turpin says that he will compensate for the loss of his pay by stealing everything he can from the humble house where he has been billeted, and he later steals a bandera that Brunel wins in battle and claims to have won it himself; Scipio, deceived, rewards the wrong one with a jewel and the end of military exile;

3) a pair of noble Roman soldier friends, Lelio and Egidio, who arrive bringing to Scipio two distinguished prisoners-Luceyo, who hides his identity as son of Hannibal and heir apparent of his «celtiberia patria» and pledged to wed the African princess Arminda who is the other noble prisoner. Lelio and Egidio take turns saving each other's lives in battle and readily yield to the other the rewards for their distinguished service, but stubbornly insist on their claim to Arminda, Lelio having fallen in love with her portrait before seeing her, and Egidio as captain of the ship that bore her to Carthage. Scipio also falls in love with her at first sight but will, of course, control his desire and unite her with Luceyo in the end.

Finally, the fourth class of 'soldiers' are the expelled Carthaginian women themselves. They, in gratitude to Scipio for his defense of them, first reveal to him where he can find a weak spot in the city's defensive walls, and then organize themselves into a female squadron to attack its gate and kill Magón and his men. When Scipio refuses to enter the conquered city, moved to see it bathed in blood, and saying "Ningún cruel fue valiente / ningún valiente fue fiero», the women yield Magón to him and he pardons him as well. In total, a spectacular and melodramatic exemplum well seasoned with comic relief for the simple-minded Carlos, the triumphant don Juan José, and the queen mother who had so long resisted his advance to power. Calderón, I suggest, modeled for don Juan José an ideal self-control and magnanimity on the part of the conqueror, for Mariana a feminine gratitude and cooperation with the victor; and for Carlos, the antics of the military equivalents of Abbot and Costello.

To conclude, what light does all this shed on the rebel soldier of La vida es sueño? Why did Calderón bring him back at the end of the

22 Calderón de la Barca, El segundo Scipión, p. 1484. 
drama, to trouble the celebratory finale 23 ? I suggest Calderón did so in order to both permit rebellion against paternal and royal injustice, and to trace clear limits to its extension or acceptability. The traditional condemnation of the soldier as a traitor is convincing as the received, rational —or rationalized - explanation of the 'justice' of such action in Calderón's day. But as Fredric Jameson points out, the process of figuration frequently reveals the points of irresolvable tension, the cracks in the smooth surface of the dominant ideology ${ }^{24}$. Reading the comedia intertextually with the auto version, in which Christ willingly serves as the pharmakos for everyman's inevitable rebellion points up the tension of class division. Although the autos underline the validity of that sacrifice for all human kind, regardless of their estamento, in the comedia, the three victims of the violence of that rebellion are all villanos; the unnamed criado whom Segismundo defenestrates; Clarín, and the rebel soldier. In La vida es sueño, it is they, and they alone, who pay the price.

23 I thank Terry O'Reilly for raising this question, in conversation at the Association of Hispanists of Great Britain and Ireland meeting in Sheffield, England, on March 26, 2008. See also Greer, forthcoming.

${ }^{24}$ Jameson, 1986, pp. 46, 48, 54. 


\section{BIBLIOGRAPHY}

Calderón de la Barca, P., La aurora en Copacabana, ed. E. S. Engling, London, Tamesis, 1994.

- El divino cazador, ed facsímile, Madrid, Ministerio de Cultura, 1981.

- El segundo Scipión, in Obras completas, Dramas, ed. Á. Valbuena Briones, Madrid, Aguilar, 1959, pp. 1455-1501.

- El sitio de Bredá, in Obras completas, Dramas, ed. Á. Valbuena Briones, Madrid, Aguilar, 1959, pp. 69-106.

- El Tuzaní de la Alpujarra, ed. M. Ruiz Lagos, Sevilla, Editorial Guadalmena, 1998.

Coenen, E., "Calderón y la Guerra: del Sitio de Bredá al sitio de Galera», Nueva Revista de Filología Hispánica, 66, 2008, pp. 31-51.

Cotarelo y Mori, E., Ensayo sobre la vida y obras de D. Pedro Calderón de la Barca, Madrid, Tip. de la Revista de Archivos, Bibliotecas y Museos, 1924.

Domínguez-Ortiz, A., «La movilización de la nobleza castellana en 1640», Anuario de Historia del Derecho Español, 25, 1955, pp. 799-824.

Elliott, J. H., The Count-Duke of Olivares: The Statesman in an Age of Decline, New Haven, Yale University Press, 1986.

Greer, M. R., «Cazadores divinos, demoníacos y reales en los autos de Calderón de la Barca», Divinas y humanas letras. Actas. Congreso Internacional sobre los autos sacramentales de Calderón de la Barca, Universidad de Navarra, Pamplona, 1997, ed. I. Arellano et al., Kassel, Reichenberger, 1997, pp. 217-242.

- «An (In)convenient Marriage: Justice and Power in La vida es sueño, comedia and auto sacramental», Bulletin of Spanish Studies, forthcoming.

- The Play of Power: Mythological Court Dramas of Pedro Calderón de la Barca, Princeton, Princeton University Press, 1991.

- "The Politics of Memory in Calderón's El Tuzaní de la Alpujarra», in Rhetoric and Reality in Early Modern Spain, ed. R. Pym, Woodbridge, England, Tamesis, 2006, pp. 113-130.

Hurtado de Mendoza, D., Guerra de Granada, ed. B. Blanco-González, Madrid, Castalia, 1970.

Jameson, F., «Religion and ideology: Paradise Lost», in Literature, Politics and Theory, ed. F. Barker et al., London, Methuen, 1986, pp. 12-56.

Kamen, H., Spain in the Later Seventeenth Century, 1665-1700, New York, Longman, 1980.

Mármol Carvajal, L. de, Historia de la rebelión y castigo de los moriscos del Reino de Granada, ed. A. Galán, Arguval, Málaga, 1991. 
McKim-Smith, G. and M. L. Welles, «Topological Tropes: The Mapping of Breda in Calderón, Callot, and Velázquez», Indiana Journal of Hispanic Literatures, 1, 1991, pp. 185-212.

Pérez de Hita, G., Segunda parte de las guerras civiles de Granada, ed. J. Gil Sanjuán, Granada, Editorial Universidad de Granada, 1998.

Stradling, R. A., Philip IV and the Government of Spain, 1621-1665, Cambridge, Cambridge University Press, 1988.

Thompson, I. A. A., War and Government in Habsburg Spain 1560-1620, London, The Athlone Press, 1976.

Varey, J. E. and C. Davis, "Calderón in 1643», in Hispanic Studies in Honour of Geoffrey Ribbans, ed. A. L. Mackenzie and D. S. Severin, Bulletin of Hispanic Studies, Special Homage Volume, Liverpool, Liverpool University Press, 1992, pp. 97-103.

Vosters, S. A., "Again the First Performance of Calderón's El sitio de Bredá», Revista Canadiense de Estudios Hispánicos, 6, 1981, pp. 117-134.

Whitaker, S. B., «The First Performance of Calderón's El sitio de Bredá», Renaissance Quarterly, 31, 1978, pp. 515-531.

Wilson, E. M., «Un memorial perdido de don Pedro Calderón», in Homenaje a William L. Fichter. Estudios sobre el teatro antiguo hispánico y otros ensayos, ed. A. D. Kossoff and J. Amor y Vázquez, Madrid, Castalia, 1971, pp. 801817. 